\title{
Identification of Suitable Rural Development Indicators
}

\author{
Rajive Gupta ${ }^{1 *}$
}

${ }^{1}$ Professor, Department of Rural Studies and Sustainability, Dev Sanskriti University, Haridwar India

*Corresponding author email: rajivekgupta@gmail.com

https://doi.org/10.36018/dsiij.v19i.238

\begin{abstract}
The objective of this paper is to identify suitable rural development indicators which are easy to compile and analyze. These indicators can also be presented at the village level depicting their current status of rural development. With increasing emphasis on local governance, Gram Panchayats will be playing a key role in the rural development process. These indicators will help the elected representatives and Panchayat officials to track their progress as well as compare the outcome of their efforts with that of other Gram Panchayats in the area of rural development. The suggested indicators have been grouped in seven broad headings such as basic data, social indicators, economic indicators, educational indicators, wellness and health indicators, access to public amenities, and natural environment indicators. These indicators will greatly help Gram Panchayats, planners, policymakers to learn and improve upon shortcomings and replicate successes achieved in rural development.
\end{abstract}

Keywords. Sustainable Development, Rural Development, Indicators

\section{INTRODUCTION}

Mahatma Gandhi had said, "The soul of India lives in its villages". The country's economy is largely dependent on the wellbeing of people in the villages where $66.7 \%$ of the total population of the county lives. Agriculture is the major economic activity in rural areas. The share of agriculture in GDP declined from over 40.47 percent in 1971 to about 12 percent in 2017-18. The anomaly of two-thirds of the population contributing only less than one-eighth to GDP could lead to serious economic consequences. This is a challenge for policymakers and governments.
Rural areas are economically backward than urban areas, therefore, their development has received priority in most of the national plans and policy documents since independence. There have also been concerted efforts to assess the impact of such policies and programs including the expenditures and investments made on various rural development programs over the years. Various studies have indicated that there have been severe regional imbalances in rural development. The vision of the Honorable Prime Minister under 'New India@ 2022' for faster economic growth of rural India includes a data-driven governance strategy for addressing regional imbalances. To compare two similar sample 
rural geographical areas or localities/villages, there has always been a need to devise simple tools and appropriate indicators that would provide the development status of these localities rationally.

\section{RURAL DEVELOPMENT AT PRESENT Defining Rural}

The term 'rural' has been defined in several ways. According to the Planning Commission of India, a town with a maximum population of 15,000 is considered rural. The National Sample Survey Office (NSSO) defines 'Rural' as (a) an area with a population density of up to 400 per square kilometer (b) villages with clear surveyed boundaries but no municipal board and (c) a minimum of 75 percent male, the working population involved in agriculture and allied activities. The Census of India 2001 only defines what is "urban" and it is implied that rural means areas which are not urban. Urban areas, as defined by the Census of India: (a) all statutory places with municipality, corporation, cantonment board, or notified town area committee. (b) Minimum population of 5,000 (c) density of population of at least 400 per square kilometer (1000 per square mile) and (c) at least 75 percent of male, the working population is engaged in non-agricultural activities. Reserve Bank of India (RBI) defines rural areas having a population of less than 49,000 as Tier 3 and Tier-6 cities (1).

In nutshell. The villages which are inhabited in areas outside the cities are called rural areas. The area is typically characterized by farmlands orchards and scattered populations.

\section{Rural Development- the need}

Development' in general refers to a process that creates growth, progress and improves the quality of life of the population without damaging the natural resources. There is a natural desire for development in human beings. The objectives of development include: to increase the availability and widen the distribution of life-sustaining goods, to raise the standard of living which include economic needs such as higher incomes, more jobs, and material needs, and non-economic needs such as better education, knowledge, and spiritual fulfillment, and expand the range of economic and social choices among other factors.

A country can attain "developed" status only when all its inhabitants, whether rural or urban, have attained overall development. In India, where, two-thirds of the population living in rural areas is contributing only 12 percent to national GDP, rings an alarm and calls for increased attention towards rural development.

"As India lives in her villages, only an inclusive, integrated and sustained rural development beholds our vision of poverty-free India founded on wellthought policy and time-bound socio-economic transformation engaging rural population at the grassroots under a collaborative and transparent public service delivery regime" (Vision Document, Ministry of Rural Development, Government of India, 2019) (2).

"Rural development is understood as the unfolding of socio-economic equity, inclusiveness, and sustainability of ecosystem in rural areas through collaborative and participative efforts of Local, States and Federal Government. Rural Development in the country calls for a package of policy and program interventions that aim to foster socio-economic change and human improvement through rural modernization and mainstreaming rural empowerment for a dignified living" (2). 
Accountability is a must in governance, in both developed and developing countries. Objective assessment of the well-being of a nation's households is an important indicator of success (3).

\section{Rural Development Strategies}

Rural development is a part of the overall national development and has been defined and explained by various scholars and academicians. The focus of rural development is the upliftment of the rural poor through various programs and policy interventions.

According to Robert Chambers (1983), "rural development is a strategy to enable a specific group of people, poor rural women, and men, to gain for themselves and their children more of what they want and need". It involves helping the poorest among those who seek a livelihood in the rural areas to demand and control more of the benefits of the rural development. The group also includes small-scale farmers, tenants, and landless (4).

Rural Development is a strategic design to improve the economic and social life of a specific group of people- the rural mass. It involves extending the benefits of development to the poorer among those who seek a livelihood in rural areas. The group includes small-scale farmers, tenants and landless" (5).

Rural development policies normally aim to make rural places economically, socially, culturally, and environmentally healthy (3).

In 2003, the United Nations Economic and Social Council - High-level segment focused on rural development. The Report of the Secretary-General, "Promoting an integrated approach to rural development in developing countries for poverty eradication and sustainable development" (2003) provides a detailed analysis of the issues facing developing countries. In particular, it highlights the following elements of an integrated approach to rural development: 1) Strengthening the rural economy, 2) Social development, 3) Sustainable use of natural resources and protection of the environment, and 4) Empowerment of the poor as a strategy for integrated rural development.

In summary, the report states: "Accelerated rural development is essential to achieve the internationally agreed development goals, including the millennium development goals. The present report provides policy recommendations on ways to promote an integrated approach to rural development, encompassing the economic, social, and environmental dimensions, with several mutually reinforcing policies and programs that address a broad range of issues related to rural development" (3).

\section{Parameters used to describe Rural development}

Researchers, policymakers, and academicians have used various parameters to describe rural development. The most common parameters used by various study groups include:

1. Availability of life-sustaining requirements food, cloth(es), and shelter

2. Health care facilities

3. Purchasing power

4. Access to Education

5. Job opportunities

6. Productivity enhancement

7. Equal opportunities and justice

8. Access to public services

9. Social security

10. Recreation and cultural activities

11. Access to technological advancement

12. Accessibility to neighborhood/town etc. 


\section{Approach to rural Development}

The government of India has undertaken a multipronged approach to rural development through its various ministries and departments that include Departments of Agriculture, Fisheries, Drinking Water, Disaster Management, Education, Health and Family Welfare, Skill Development, Women and Child Development, Food and Civil Supplies, Irrigation, etc.

The Ministry of Panchayati Raj and Rural Development is the nodal agency handling rural development programs in convergence with other ministries and departments. The budgetary provision of the Rural Development Ministry has increased from Rs. 58,630 crore in $2013-14$ to Rs. $1,17,647$ crore in 2018-19. During this period a total of over Rs. 6.3 lakh crore has been invested by the Ministry of rural development on various programs and schemes for rural development in the country such as Mahatma Gandhi National Rural Employment Act (MGNAREGA), (Pradhan Mantri Gram Sadak Yojana (PMGSY), Pradhan Mantri Gramin Awas Yojana (PMGAY), National Rural Livelihood Mission (NRLM), Deen Dayal Upadhyaya Grameen Kaushalya Yojana (DDU-GKY), National Social Assistant Program (NSAP), Shyama Prasad Mukherji Rurban Mission (SPMRM) (2).

\section{Impact Assessment of Rural Development Programs}

Data on a host of parameters covering various aspects of rural development can be accessed through Census, NSSO reports, websites and annual reports of the Ministries concerned which can be put to analysis as per the requirement. The National Institute of Rural Development and Panchyati Raj (NIRDPR), Hyderabad (Ministry of Rural Development Government of India) has also been compiling, updating, and publishing 'Rural Development Statistics' regularly that could also be used for studying and monitoring rural development including Social Development Index (SDI), Multidimensional Poverty Index (MPI) and Human Development Index (HDI), etc (6).

To monitor and ensure the efficient and effective delivery of various rural development programs and take corrective measures wherever necessary, the Government of India carries out its impact assessment of individual programs/schemes through reputed national-level organizations. A few such studies are described in the following paragraphs.

\section{'Rapid Assessment of Natural Resource Management} Component under MGNAREGA and its impact on sustainable livelihoods' carried out by the Institute of Economic Growth (IEG), New Delhi in 2017 (7) studied the impact of individual and community Natural Resource Management assets on participating households concerning three broad parameters viz. productivity, income and migration. In another quick mid-term assessment study taken up in 15 states on 'Performance of Mission Antyodaya Gram Panchyats' by the National Institute for Rural Development and Panchayati Raj (NIRDPR), Hyderabad (2018) used 37 indicators about six key parameters as (i) infrastructure, (ii) economic development \& livelihoods, (iii) health, nutrition, sanitation, (iv) women empowerment and (v) financial inclusion. The Institute of Rural Management (IIM)), Ahmedabad carried out a 'PMGSY Outcome Monitoring Study' in 2017 and the outcome was measured in terms of perception of Speed Gain and Time Saved. The Impact was measured by the perception of improvement in health, education, safety, economic activity, environment/safety, etc. using 26 variables (9). 
Similarly, the Institute of Rural Management, Anand (IRMA) carried out a study in 2017 "Independent Assessment of Design, Strategies, and Impacts of DAY-NRLM". In its Impact Evaluation of DAYNRLM using Micro-Econometric Approach, it provided impacts of DAY-NRLM on asset ownership, consumption, income and livelihoods, seasonal migration, participation in MGNREGS, savings, investment and debt, and participation in SHGs and governance using quasi-quantitative assessment of the impacts of DAY-NRLM on 22 major variables. The variables include women empowerment, enhancement of self-esteem of women, personality development of women, reduction in social evils, social cohesion, access to micro-finance, high-cost debt reduction, financial stability, income, livelihood diversification, livestock production, standards of living, education, sanitation and health, water supply and irrigation, agricultural production, agricultural techniques, augmentation of natural resources, infrastructure development, institutional building, access to government schemes, and participation in village institutions (10).

The above studies provide the program-specific and objective-based outcomes that may help the planners and policymakers to improve the program accordingly. Similarly, indicators were developed by various researchers which facilitated assessment as well as comparison of the progress made in those preidentified areas as may be required. These indicators also reflected the developmental aspects but were specific to the study objectives.

\section{DEVELOPMENT OF RURAL DEVELOPMENT INDICATORS - AN OVERVIEW}

To improve rural development program design and efforts, key indicators of rural development or Rural Development Index (RDI) have been developed by various academicians and scholars. In Europe, Zekić et.al 2017 chose twelve national-level indicators which were directly or indirectly linked to the level of rural development viz. Rural territory (\% of total area), X2: Rural population (\% of the total population), Rural GDP ( $\%$ of total GDP), Rural employment (\% of total employment), Agriculture (\% of GDP), Average economic farm size, Labour productivity in agriculture, Farmers with other gainful activity (\%), Adults with medium or high educational attainment in rural areas (\%), GDP per capita, Internet users (per 100 people), Environmental protection expenditure (EUR per capita). The variables are related to the general development of the country as well as to agricultural and rural development (11). Michalek and Zarnekow (2011) constructed a multi-dimensional (Composite) index measuring the overall level of rural development and quality of life in individual rural regions of a given EU country. In the Rural Development Index (RDI) the rural development domains were represented by hundreds of partial socio-economic, environmental, infrastructural, and administrative indicators (991 variables in Poland and 340 variables in Slovakia) (12).

Kim \& Yang (2016) developed a Rural Development Index that can be used to comprehensively evaluate the level of development and the progress of development projects in rural areas. The Index was composed of Result Index' and a 'Cause Index' in five major domains of analysis: 1) economy, 2) education, 3) health and welfare, 4) environment, and 5) culture and leisure. The study covered 60 indicators (13). Banakar and Patil, 2018 also worked on the concept of RDI and developed an index to compare the extent of development in rural places and to assess the development of the rural areas from different dimensions using a conceptual index which 
is a composition of Result Index and Cause Index. The proposed conceptual index was composed of five domains viz. 1. Economy 2. Education 3. Health 4. Environment 5. Culture and Leisure (14).

Mathur (2005) developed 25 rural development composite indices spread over nine broad groups covering various domains of rural landscape viz. agricultural production capacity, workforce diversity, educational infrastructure, health infrastructure, amenities, transport infrastructure, human capital in the workforce, financial infrastructure, and standard of living (15).

World Bank (2002) published a Rural Development Indicators Handbook which has World Development Indicators. The handbook provides a guideline to develop a common approach to monitoring and evaluating progress within a country, and across several countries, using a clearly defined set of indicators. It also gives data for computing the Rural Score Card, a composite indicator, that could be used to assess the overall progress made in achieving rural well-being (poverty reduction) for a country. There are 45 indicators under seven broad categories viz. Basic data, rural economic performance, natural resource management, Rural well-being, Human asses (education and health), physical assets (infrastructure and communication), and food security under which various developed, developing, and underdeveloped countries were evaluated (16).

The European Commission gathers socio-economic, sectorial, and environmental statistics based on 45 indicators as bases for an informed and data-driven common agricultural policy (CAP Context Indicators 2014-19, ec.europa.eu).
A brief account of the set of indicators developed by major international organizations have been provided in the Wye Group Handbook on Rural Households' Livelihood and Well-Being (2007) developed jointly by the Food and Agriculture Organization of the United Nations (FAO), Organisation for Economic Co-operation and Development (OECD), The World Bank and the Statistical Office of the European Communities (Eurostat) for the benefit of various groups concerned with rural development and the evolving nature of the agricultural industry (3).

The OECD identified four general subjects with a set of 20 indicators, which cover the range of rural development like population and migration, economic structure and performance, social wellbeing and equity, environment, and sustainability. European Union identified 55 indicators that were considered to represent "good practice" in addressing the needs of rural development policymakers and practitioners these include population and migration, demographic structure and evolution, Social wellbeing, quality of life economic structure and performance,

The World Bank prescribed 81 core indicators for developing countries from five themes - basic socioeconomic data; enabling environment for rural development, broad-based economic growth for rural poverty reduction, natural resource management, and biodiversity.

FAO identified 11 core indicators for monitoring poverty alleviation under two broad headings: poverty alleviation with equity and access to land, water, and other natural resources from the set of 19 primary indicators listed in the World Conference on Agrarian Reforms and Rural Development (WCARRD) (3). 
THE PROPOSED RURAL DEVELOPMENT INDICATORS

Rural areas in India are characterized by diverse social, economical, political, geographical settings and call for a multi-pronged approach to rural development. Since rural development is a complex, multidimensional concept, rural conditions and trends cannot be described by a single yardstick. To cover the various perspectives, a whole set of indicators have to be identified. Moreover, changing rural scenarios due to several developmental schemes and policies, the indicators also need to change over time to capture the accurate picture of rural development.

Rural development indicators depicting socioeconomic scenarios viz. education, health, nutrition, basic amenities (like water, sanitation, electricity, communication, road, etc.) have been improving over the years. However, they cannot be compared with urban development indicators.

As discussed in earlier paragraphs, a vast amount of data and information on rural development is available in publications, census, NSSO, and, websites of various ministries/departments of the Government of India. This data forms the basis of planning, monitoring, and evaluation of the rural development programs.

It is suggested that the selection of an indicator should be based on objectivity, relevance, understanding, and the information needed to be easily available. Uniformly measurable indicators are helpful for statistical analysis, wherever needed. Wherever required highly related indicators need to be grouped in the form of Summary indicators. Acknowledging that these indicators will be used for comparing two rural regions to reflect the efficiency of governance and delivery system, the careful selection of indicators is of paramount importance. The selected indicators must be able to reflect the following for that area:

1. The status of the overall development

2. The human, social, financial capital

3. Infrastructural facilities (that will provide a platform for future development)

4. Natural resources and their conservation

5. Community working

6. Areas of Deficiencies

Accordingly, the following indicators have been chosen which are specific and comparable. The indicators have been grouped under seven broad headings.

\section{Basic data}

Crop husbandry continues to be the main occupation in rural areas. The pressure on land, crop productivity are the important indicators that provide the status of agriculture in that area. The crop productivity is also influenced by the availability of irrigation and average landholding which determines the extent of mechanization. This basic data will also reflect on how agriculture has been doing in that area over the years and is easy to use for comparison with another area.

\section{Social indicators}

The social indicators reveal the standard of living as well as a demographic picture of the area. An efficient and well-developed communication network indicates a well-developed and informed society. The use of clean energy, the durable build of the house, availability of electrical durables, electronic gadgets and motorbikes, accessibility to the internet, newspapers reflect the improved living conditions and economic development. A higher female to male ratio indicates greater respect for women in society. The younger or older population indicates the 
working adult population in the area and the prospects.

\section{Economic Indicators}

Rural development aims to support and encourage activities to increase the income of the rural population by diversification or intensification of agricultural activities, to increase rural industry, and finally to increase capacity building in those areas. Rural industrial activity not only adds value to agricultural produce but also creates employment opportunities for rural people locally. These activities also reflect the promotion of rural entrepreneurship and the development of an environment for innovation in rural areas. Average per capita expenditure continues to be an important measure of rural development in the country. Marketing facilities and services are the prime movers of economic development of the rural area for they provide channels of effective and efficient flow of goods and services to and from urban centers. The steps taken by people in mitigating the risk through appropriate insurance coverage are also captured through these indicators.

\section{Educational Indicators}

Skilled manpower resources form the basis of effective and efficient utilization of available resources in rural areas. The quality of the workforce is more important than the number of people in the workforce. It has been established that to develop, a country needs its people to be educated and skilled. Education helps people to develop traits required for future developments and equips them to be less vulnerable during a crisis. The foundation of education is laid during the early period of primary and secondary education. The indicators provide information on how the people of the rural area are working towards building its future generation a responsible and productive workforce. Efforts being made on adult education, an important aspect of the development program are also captured through one of the indicators.

\section{Well-being and health}

Health is an important aspect of human capital. A developed and well-established health infrastructure is not only desirable but also essential for rural people. Life expectancies, malnutrition, immunization, birth mortality, Anganwadi enrollment, availability of medical infrastructure and support staff, people opting for health insurance, and occurrence of serious illness among the rural folks are some important indicators of rural health and wellbeing.

\section{Access to public amenities}

Creating a favorable environment for rural development by improving infrastructure, improved accessibility of public services for rural people is the goal of the Government. Electricity is a vital input for domestic, agricultural, and rural-based industries. Rural roads are important for the movement of people and goods to and from rural areas. Similarly, effective delivery of amenities like banks, ATMs, post offices, drinking water supply, availability of all-weather roads, availability of public transport, library, school, hospital, entertainment facilities, etc. to rural people is captured through these indicators.

\section{Environment Indicators}

These indicators provide information on the maintenance and protection of the rural environment. Forest, wells, and ponds in rural areas are boons to rural society. Well-managed common grazing land in the village encourages animal husbandry, A wellmanaged solid waste, and drainage system improves sanitation and the rural environment. The details of the indicators under each broad group are given in table 1 . 


\begin{tabular}{|c|c|}
\hline $\mathrm{Sr}$ & Indicator Group and sub-points \\
\hline 1 & Basic data \\
\hline 1.1 & Total Area ( ha) \\
\hline 1.2 & Population density (No of persons/sq Km) \\
\hline 1.3 & Total Cropped area (\%) \\
\hline 1.4 & Irrigated Land (\%) \\
\hline 1.5 & Average Landholding (ha) \\
\hline 1.6 & $\begin{array}{l}\text { Average Productivity ( } Q / \text { ha) of major crops of the } \\
\text { area }\end{array}$ \\
\hline 2 & Social Indicators \\
\hline 2.1 & Female: Male Ratio \\
\hline 2.2 & Younger Population below 18 years (\%) \\
\hline 2.3 & Older Population above 60 years (\%) \\
\hline 2.4 & Below Poverty Line families (\%) \\
\hline 2.5 & Mobile Phones per 1000 persons \\
\hline 2.6 & $\%$ of Houses that own TV \\
\hline 2.7 & $\%$ of Houses that have Computers/Laptop \\
\hline 2.8 & $\%$ of Houses that use the Internet \\
\hline 2.9 & $\%$ of Houses that receive Newspapers \\
\hline 2.10 & $\%$ of houses with Pakka construction \\
\hline 2.11 & $\%$ of houses that use LPG \\
\hline 2.12 & $\%$ of houses that have two /four wheelers \\
\hline 3 & Economic Indicators \\
\hline 3.1 & Value of total production (Rs.) \\
\hline 3.2 & Average Income per person (Rs.) \\
\hline 3.3 & Average per capita expenditure (RS.) \\
\hline 3.4 & $\%$ of people employed outside the rural area \\
\hline 3.5 & $\%$ of people -Skilled \\
\hline 3.6 & $\%$ of people as Landless laborers \\
\hline 3.7 & $\begin{array}{l}\% \text { persons having the non-farm income } \\
\text { (sericulture, animal husbandry and dairying, } \\
\text { poultry, bee-keeping, fishery, etc) }\end{array}$ \\
\hline 3.8 & $\begin{array}{l}\% \text { households connected with Farmers } \\
\text { Producers Organization }\end{array}$ \\
\hline 3.9 & $\begin{array}{l}\% \text { Household connected with women self-help } \\
\text { groups }\end{array}$ \\
\hline 3.10 & $\%$ of people as Self-employed artisans/craftsmen \\
\hline 3.11 & $\%$ of People engaged in Agro-processing \\
\hline 3.12 & $\%$ of People opting for crop insurance (\%) \\
\hline 3.13 & $\%$ of people opting for Life Insurance \\
\hline 3.14 & $\%$ of persons received vocational Training \\
\hline 3.15 & $\%$ of People having a bank account \\
\hline 3.16 & Fertilizer/Agri input shops \\
\hline 3.17 & Access to daily information on Mandi rates \\
\hline 4 & Educational Indicators \\
\hline 4.1 & $\%$ Literacy- Male \\
\hline 4.2 & $\%$ Literacy - Female \\
\hline 4.3 & $\%$ of Children enrolled in Primary school \\
\hline
\end{tabular}

Table 1. Proposed Indicators for Rural Development

\begin{tabular}{|c|c|}
\hline 4.4 & $\%$ of Children enrolled in Secondary school \\
\hline 4.5 & $\%$ Attendance - Primary School \\
\hline 4.6 & $\%$ Attendance - Secondary School \\
\hline 4.7 & Children dropout (\%)- Primary School \\
\hline 4.8 & Children dropout (\%)- Secondary School \\
\hline 4.9 & $\begin{array}{l}\% \text { of } 12^{\text {th }} \text { pass students attending } \\
\text { College/University }\end{array}$ \\
\hline 4.10 & Number of students/Primary Teachers \\
\hline 4.11 & Number of students/Secondary Teachers \\
\hline 4.12 & No. of trainers working for Literacy Programme \\
\hline 5 & Wellbeing and Health \\
\hline 5.1 & Life Expectancy (Years)- Male \\
\hline 5.2 & Life Expectancy (Years)- Female \\
\hline 5.3 & Number of doctors/ 1,000 persons \\
\hline 5.4 & Number of paramedical staff $/ 1,000$ persons \\
\hline 5.5 & No. of hospital beds $/ 1,000$ persons \\
\hline 5.6 & No. of medical shops $/ 1,000$ persons \\
\hline 5.7 & Infants with low birth weight (\%) \\
\hline 5.8 & $\%$ of Children Immunized \\
\hline 5.9 & Child Mortality (\%) \\
\hline 5.10 & $\%$ of people opting for medical insurance (\%) \\
\hline 5.11 & $\%$ Children enrolled in Anganwadi \\
\hline 5.12 & $\begin{array}{l}\% \text { of persons suffering from serious illnesses } \\
\text { (AIDS/TB etc) }\end{array}$ \\
\hline 6 & Access to Public amenities \\
\hline 6.1 & Number of Banks per 1,000 persons \\
\hline 6.2 & Number of ATMs per 1,000 persons \\
\hline 6.3 & Number of Post Office per 1,000 persons \\
\hline 6.4 & Number of Schools per 1,000 persons \\
\hline 6.5 & Number of Hospitals per 1000 persons \\
\hline 6.6 & $\begin{array}{l}\% \text { of houses having access to clean drinking } \\
\text { water }\end{array}$ \\
\hline 6.7 & $\%$ of houses having Electricity \\
\hline 6.8 & Availability of all-we road to nearest towns \\
\hline 6.9 & Availability of Public Transport \\
\hline 6.10 & Availability of Theaters/Cinema Hall \\
\hline 6.11 & Availability of Public library \\
\hline 6.12 & Availability of Multipurpose Public Service Centre \\
\hline 6.13 & Availability of Community Centre \\
\hline 7 & Environment Indicators \\
\hline 7.1 & No. of wells $/ 1,000$ households \\
\hline 7.2 & No. of Ponds/1000 households \\
\hline 7.3 & Gochar/grazing land in ha /1000 animals \\
\hline 7.4 & Forest area in ha \\
\hline 7.5 & $\%$ of houses with own toilets (\%) \\
\hline 7.6 & $\begin{array}{l}\% \text { of People having Sewage/drainage water } \\
\text { connection }\end{array}$ \\
\hline 7.7 & $\%$ of Solid Waste is Managed/disposed \\
\hline
\end{tabular}




\section{CONCLUSION}

Sustainable rural development is vital for poverty eradication The social and economic indicators of rural development have been improving over the years. Yet there are some serious regional imbalances that are a matter of concern to policymakers and implementing agencies. Government strives to address these imbalances by changing its approach and various modified policy interventions. It is also reflected in the Vision of Hon'ble Prime Minister under New India@2022 for faster economic growth of rural India and data-driven governance strategy for addressing regional imbalances. The regional imbalances can be studied using various rural development indicators. The individual development programs of the Government are monitored based on the pre-designed and well-conceived parameters. However, this paper suggests that the overall development of a rural area can be studied through suggested seven broad rural development indicators. These indicators can be efficiently and effectively used for comparing the status of rural development of two or more regions. The data compilation for suggested indicators is easy and makes a comparison of the regional differences more relevant and understandable. The researchers and academicians may use the appropriate statistical tools for further analysis using a few or several of these indicators as per their study requirements.

Funding: The author declared no specific grant for this research from any funding body i.e. public, commercial or not-for-profit sectors, etc.

Competing interests: None declared.

Patient consent for publication: Not required.

\section{REFERENCES}

1. Kumar Dinesh and Gupta Punam. Rural MarkeingChallenges and Opportunities, SAGAE Publications India Pvt. Ltd., New Delhi. 2019

2. Department of Rural Development. Vision Document 2019-2024 Transforming lives and livelihoods through proactive socio-economic inclusion, integration and empowerment of rural India. Ministry of Rural Development, Government of India, New Delhi. 2019.

3. United Nations (UN). The Wye Group Handbook Rural Households' Livelihood and Well-Being- Statistics on Rural Development and Agriculture Household Income' United Nations, New York and Geneva, Publication. 2007. ISBN 978-92-1-116967-6

4. Chambers Robert. Rural Development: putting the lastfirst. Essex, England: Longmans Scientific and Technical Publishers; New York: John Wiley. 1983. https://www.sociologydiscussion.com/india/ruraldevelopment/rural-development-in-india-sociology/13519

5. World Bank. Rural Development Sectoral Policy Paper, Report No. 10272, February, 1975 Page-3.

6. National Institute of Rural Development and Panchayati Raj (NIRDPR). Rural Development Statistics 2017-18 (Eds.) Rangacharyulu, S.V. and Sathyapalan, J. Department of Rural Development, Ministry of Rural Development, Government of India.,Rajendranagar, Hyderabad. 2019

7. Institute of Economic Growth (IEG), New Delhi. Rapid Assessment of Natural Resource Management Component under MGNREGA and its impact in sustainable livelihoods. 2017 https://rural.nic.in

8. National Institute of Rural Development and Panchayati Raj (NIRDPR). 2018. Performance of Mission Antyodaya Gram Panchayats - A Quick Mid-term Assessment Study to track the Progress Centre for Planning, Monitoring and Evaluation. 2018. https://rural.nic.in 
9. Jain, Rekha, Raghuram, G. Morris Sebastian. PMGSY Outcome Monitoring Study, Indian Institute of Management Ahmedabad. 2017 https://rural.nic.in

10. Institute of Rural Management Anand (IRMA).Independent Assessment of Design, Strategies, and Impacts of DAY-NRLM. 2017. https://rural.nic.in (accessed on 31.3.21)

11. Stanislav Zekić, Žana Kleu, Bojan Matkovski An Analysis of Key Indicators of Rural Development in Serbia: A comparison with EU Countrie. Economic Annals 57(214): 107-120. 2017 https://doi.org/10.2298/EKA1714107Z

12. Michalek, J. and Zarnekow, N. Application of the Rural Development Index to analysis of rural regions in Poland and Slovakia. Social Indicator Research. 2012;105:1-37. https://doi.org/10.1007/s11205-010-9765-6

13. KimTae-Hwa and Yang Seung-Ryong. Construction of Roral Development Index : The case study of Vietnam. Journal of Rural Development 39 (Special Issue):113 142, 2016

https://doi.org/10.18631/jalali.2016..71.003

14. Banakar1, V. and Patil S.V. A Conceptual Model of Rural Development Index. International Journal of Rural Development, Environment and Health Research(IJREH) 2(4),:29-38, 2018.

https://doi.org/10.22161/ijreh.2.4.4

15. Mathur, Ashok.. Rural Development: Indices and Linkages India: Rural Development Report-Rural Institutions , National Institute of Rural Development, Ministry of Rural Development, Government of India, Hyderabad, 2005. (quoted in Katar Singh's , Gramin Vikas Sidhant, Nitiyan evam Prabandh, 3rd Edition 2017, Sage Publications India Pvt Ltd., New Delhi.

16. World Bank. Rural Development Indicators Handbook from the World Development Indicators, 3rd Edition 2002. International Bank for Reconstruction and Development, The World Bank, Washington D.C. 